ISSN: 2302-8556

E-Jurnal Akuntansi Universitas Udayana

Vol.27.2.Mei (2019): 1365-1393

DOI: https://doi.org/10.24843/EJA.2019.v27.i02.p20

\title{
Pengaruh Corporate Social Responsibility dan Intellectual Capital Pada Kinerja Keuangan
}

\author{
Made Cahyani Prastuti ${ }^{1}$ \\ I G.A.N. Budiasih ${ }^{2}$
}

${ }^{1,2}$ Fakultas Ekonomi dan Bisnis Universitas Udayana (Unud), Bali, Indonesia
e-mail: cahyanipras@gmail.com

\begin{abstract}
ABSTRAK
Tujuan dari penelitian ini adalah untuk mengetahui bagaimana pengaruh corporate social responsibility dan intellectual capital pada kinerja keuangan. Teori yang digunakan adalah teori stakeholder, legitimasi, dan resource based theory. Penelitian ini dilakukan pada perusahaan perdagangan yang terdaftar di Bursa Efek Indonesia tahun 2015-2017. Jumlah sampel yang diambil sebanyak 26 perusahaan, dengan metode non-probability sampling dengan teknik purposive sampling. Pengumpulan data dilakukan melalui observasi nonpartisipan. Teknik analisis yang digunakan adalah analisis statistik deskriptif, asumsi klasik, dan analisis linier berganda. Berdasarkan hasil analsis ditemukan bahwa corporate social responsibility tidak berpengaruh pada kinerja keuangan. Hal ini menandakan bahwa tinggi rendahnya pengungkapan CSR tidak akan berdampak pada kinerja keuangan sektor perdagangan. Hipotesis kedua menyatakan bahwa intellectual capital berpengaruh positif pada kinerja keuangan. Hal ini mengindikasikan jika semakin tinggi intellectual capital maka semakin tinggi pula kinerja keuangan perusahaan. Kombinasi intellectual capital dapat meningkatkan keunggulan bersaing bagi perusahaan.
\end{abstract}

Kata kunci: Kinerja keuangan, corporate social responsibility, intellectual capital

\begin{abstract}
The aim of this research is to know the influence of corporate social responsibility and intellectual capital on financial performance. Theories used are stakeholder, legitimacy, and resource-based theory. This research conducted on trading companies listed on the Indonesia Stock Exchange in 2015-2017. The samples taken were 26 companies, by nonprobability sampling method with purposive sampling technique. Data collected through non-participant observation. The analysis techniques used are descriptive statistical analysis, classical assumptions, and multiple linear analysis. Based on the analysis found that corporate social responsibility has no effect on financial performance. This indicates that the high and low disclosure of CSR will not affect the financial performance of the trade sector. The second hypothesis states that intellectual capital has a positive effect on financial performance. This indicates that the higher the intellectual capital, the higher the financial performance of the company. Combination of intellectual capital can enhance competitive advantage for companies.
\end{abstract}

Keywords: Financial performance, corporate social responsibility, intellectual capital

\section{PENDAHULUAN}

Kinerja keuangan menjadi faktor utama dan sangat penting untuk menilai

keseluruhan kinerja perusahaan itu sendiri, mulai dari penilaian aset, utang, dan

modal. Kinerja perusahaan dapat dinilai dengan melakukan analisis terhadap 
laporan keuangannya. Kinerja keuangan yang diproksikan dengan Return on Assets (ROA) menyebabkan para pembaca laporan keuangan dapat memantau perkembangan perusahaan secara periodik. ROA merupakan parameter untuk mengukur profitabilitas karena akan terlihat kemampuan perusahaan dalam memanfaatkan total aset yang dimilikinya untuk memperoleh laba selama beroperasi. Semakin besar ROA, maka semakin baik kinerja keuangan perusahaan tersebut (Abriyani et al., 2012). Hal tersebut pula memberikan dampak akhir pada peningkatan kesejahteraan yang dinikmati oleh pemegang saham (Harun, 2016).

Badan Pusat Statistik (BPS) melaporkan pertumbuhan ekonomi Indonesia mencapai angka tertinggi sebesar 5,07 persen di 2017, angka ini lebih tinggi dari 2016 yang sebesar 5,03 persen, dan tahun 2015 sebesar 4,88 persen. Sektor perdagangan dipilih karena sektor ini berkontribusi 13,01 persen yang merupakan salah satu sumber pertumbuhan perekonomian Indonesia. Dari sektor perdagangan, BPS mencatat, perdagangan besar dan eceran pada kuartal keempat 2017 tumbuh 4,47 persen dibandingkan kuartal keempat tahun sebelumnya. Hasil yang berbeda ditemukan pada hasil rata-rata ROA perusahaan sektor perdagangan pada tahun 2016 yang cenderung menurun dari tahun sebelumnya.

Tabel 1.

Rata-rata Return on Assets (ROA) Perusahaan Sektor Perdagangan yang Tercatat di BEI Periode 2015-2017

\begin{tabular}{cc}
\hline Tahun & ROA \\
\hline 2015 & $4,38 \%$ \\
2016 & $3,16 \%$ \\
2017 & $3,55 \%$ \\
\hline
\end{tabular}

Sumber: Data diolah, 2018

Berdasarkan Tabel 1 menunjukkan bahwa perkembangan rata-rata ROA perusahaan sektor perdagangan yang terdiri dari perdagangan besar barang 
produksi dan perdagangan eceran tergolong fluktuatif sebagai fenomena ekonomi yang menarik perhatian. Kinerja keuangan perusahaan yang diukur dengan ROA mengalami penurunan dari tahun 2015-2016 dari 4,38 persen menjadi 3,16 persen. Penurunan ini disebabkan oleh penurunan daya beli masyarakat sejak tahun 2015 dan diluncurkannya Paket Kebijakan Ekonomi XIV oleh pemerintah pada tahun 2016. Paket Kebijakan Ekonomi XIV memuat tentang peta jalan (roadmap) sistem perdagangan nasional berbasis elektronik yang mendorong semakin berkembangnya e-commerce di Indonesia. Data Bursa Efek Indonesia menunjukkan prosentase ROA perusahaan sektor perdagangan yang fluktuatif mengindikasikan kemampuan manajemen perusahaan dalam hal mengelola aktiva untuk meningkatkan pendapatan dan/atau menekan biaya tersebut tidak konsisten. ROA perusahaan mengalami kenaikan pada tahun 2016-2017 dari 3,16 persen menjadi 3,55 persen. Pada periode ini beberapa toko retail menutup gerai untuk melakukan efisiensi biaya yang diakibatkan oleh pergeseran pola konsumsi masyarakat dari offline menuju online.

Pesatnya perkembangan teknologi informasi di era globalisasi saat ini memicu berbagai macam inovasi dan persaingan dalam perkembangan ekonomi dan bisnis. Entitas berlomba-lomba untuk membenahi perusahaannya agar dapat meningkatkan kualitas serta kinerjanya. Indonesia sebagai bagian dalam kawasan regional Asia Tenggara mempunyai tantangan dalam menghadapi satu pasar bebas dalam kawasan Asia Tenggara yang dikenal dengan nama Masyarakat Ekonomi Asean (MEA). Diberlakukannya MEA menyebabkan perusahaan- 
perusahaan di Indonesia menghadapai suatu tantangan untuk merebut peluang pasar dalam lingkungan bisnis yang semakin kompetitif.

Strategi untuk mampu bertahan dalam persaingan yang semakin berat ini, perusahaan harus memiliki nilai yang dapat menciptakan keunggulan bersaing (competitive advantage) dengan cara tidak hanya mengandalkan aset berwujudnya (tangible assets), namun juga harus mulai memanfaatkan aset tidak berwujud (intangible assets) yang dimilikinya (Noorkhaista dan Sari, 2017).

Beberapa faktor non finansial yang dapat meningkatkan kinerja perusahaan seperti Corporate Social Responsibility dan Intellectual Capital menjadi hal yang semakin dipertimbangkan oleh para stakeholder. Hal tersebut perlu dipertimbangkan mengingat maraknya kasus pencemaran lingkungan dan kegiatan yang merugikan masyarakat. Corporate Social Responsibility (CSR) merupakan suatu program tanggung jawab perusahaan terhadap sosial dan lingkungan di sekitar perusahaan seperti pemerintah, karyawan, dan konsumen. Konsep yang dikemukakan oleh John Elkington (1998) yaitu The Triple Bottom Line menyatakan bahwa agar perusahaan dapat menjaga kelangsungan hidupnya maka harus memperhatikan 3P, yaitu Profit, Planet, dan People. Pengungkapan CSR merupakan salah satu cara agar perusahaan mengelola usahanya tidak hanya untuk kepentingan para pemegang saham (shareholder) tetapi juga untuk pihakpihak lain di luar perusahaan yang disebut sebagai stakeholder seperti pemerintah, lingkungan, para pekerja, komunitas, supplier, bahkan juga kompetitor.

Kesadaran akan pentingnya penerapan corporate social responsibility sudah mulai berkembang di Indonesia. Hal ini dibuktikan dengan diterbitkannya 
Undang-Undang No. 40 tahun 2007 tentang Perseroan Terbatas, selanjutnya dilengkapai dengan Peraturan Pemerintah Republik Indonesia No.47 tahun 2012 tentang Tanggung Jawab Sosial dan Lingkungan Perseroan Terbatas. UndangUndang Penanaman Modal No.25 tahun 2007 juga mengatur kewajiban pelaksanaan CSR, pada Pasal 15 bagian b, Pasal 17, dan Pasal 34 yang menyebutkan bahwa setiap penanam modal diwajibkan untuk ikut serta dalam tangung jawab sosial perusahaan. Hal tersebut juga disusul dengan dikeluarkannya Peraturan Daerah Kabupaten Badung No. 63 tahun 2013, Peraturan Daerah Kalimantan Selatan No. 1 tahun 2014, Peraturan Daerah Provinsi Jawa Tengah No. 2 tahun 2017.

Corporate Social Responsibility dapat digunakan sebagai alat marketing baru bagi perusahaan bila dilaksanakan secara berkelanjutan. Dengan melaksanakan CSR, citra perusahaan akan semakin membaik sehingga loyalitas konsumen akan semakin meningkat terhadap perusahaan. Seiring dengan meningkatnya loyalitas konsumen maka akan meningkatkan profitabilitas kedepannya, pernyataan ini diperkuat dengan penelitian yang dilakukan oleh Ghoul et. al. (2011) yang menyatakan bahwa perusahaan yang melakukan praktik tanggung jawab sosial memiliki valuasi yang lebih tinggi dan risiko yang lebih rendah. Perusahaan yang mendapatkan penghargaan dibidang CSR juga dapat memberikan indikasi bahwa organisasinya telah berkontribusi kepada masyarakat dan patut diapresiasi. Penelitian yang dilakukan Wulandari dkk. (2016) juga mengungkapkan beberapa dampak positif dari penerapan CSR diantaranya bisa membangun positioning merk, mendongkrak penjualan, memperluas pangsa 
pasar, meningkatkan loyalitas karyawan, serta meningkatkan daya tarik perusahaan di mata investor. Ini menunjukkan bahwa adanya pengaruh CSR pada profitabilitas perusahaan secara berkelanjutan.

Menurut teori stakeholder, perusahaan harus menjaga hubungan dengan stakeholder-nya dengan mengakomodasi keinginan dan kebutuhan stakeholdernya yang mempunyai power terhadap ketersediaan sumber daya yang digunakan untuk aktivitas operasional perusahaan, misalnya tenaga kerja, pasar atas produk perusahaan dan lain-lain (Ghozali dan Chariri, 2007). Bisnis yang dijalankan oleh perusahaan tidak hanya bermanfaat bagi para pemilik modal saja tetapi juga untuk masyarakat di sekitar perusahaan maupun masyarakat luas. Perusahaan dalam mencapai tujuannya memerlukan adanya sinergi antara hubungan timbal balik antara perusahaan dengan masyarakat, karyawan, dan investor tentunya (Umawan dan Putri, 2017). Dengan melakukan kegiatan CSR perusahaan berharap memperoleh legitimasi dari masyarakat dan mempertahankan hubungan dalam lingkungan sosial dimana mereka beroperasi. Tanpa adanya legitimasi perusahaan tidak akan mampu bertahan, oleh karena itu perusahaan perlu melakukan pengungkapan terhadap lingkungan di sekitar perusahaan (Jananti dan Setiawan, 2018)

Beberapa penelitian telah membuktikan bahwa corporate social responsibility (CSR) berpengaruh pada kinerja keuangan. Pada penelitian Gantino (2016) menemukan bahwa CSR berpengaruh positif signifikan pada ROA. Corporate Social Responsibility juga berpengaruh positif pada kinerja keuangan perbankan yang diproksikan dengan ROA (Mariyantini dan Putri, 2018). 
Berdasarkan penelitian Mukharomah dan Kesumaningrum (2014) menemukan bahwa CSR berpengaruh pada ROA pada perusahaan Food and Beverages di Bursa Efek Indonesia.

Berdasarkan fenomena terjadinya fluktuasi kinerja keuangan dan perkembangan perusahaan di era perekonomian modern dan global saat ini, membuat para pelaku bisnis mulai menyadari bahwa kemampuan bersaing perusahaan tidak hanya terletak pada kepemilikan aset berwujud, melainkan pada inovasi, sistem informasi, pengelolaan organisasi, dan sumber daya manusia yang dimilikinya. Agar perusahaan mampu bvaictertahan dalam persaingan, perusahaan dituntut untuk mulai mengubah strategi bisnis yang awalnya didasarkan pada tenaga kerga (labor-based business) menuju bisnis yang berdasarkan pengetahuan (knowledge-based business) (Hermawan dan Mardiyanti, 2016). Oleh karena itu, organisasi bisnis semakin menitikberatkan pada pentingnya aset pengetahuan (knowledge assets) (Sawarjuwono dan Kadir, 2003)

Salah satu pendekatan yang digunakan untuk menilai dan mengukur aset pengetahuan adalah modal intelektual (Guthrie dan Petty, 2000). Modal intelektual atau intellectual capital (IC) merupakan suatu konsep yang dapat memberikan sumber daya berbasis pengetahuan baru dan mendeskripsikan aset tak berwujud yang jika digunakan secara optimal memungkinkan perusahaan untuk menjalankan strateginya dengan efektif dan efisien. Williams (2001) mendefinisikan intellectual capital sebagai informasi dan pengetahuan yang diaplikasikan dalam pekerjaan untuk mencapai nilai. Penciptaan nilai bagi perusahaan terjedi ketika perusahaan mampu mengolah sumber daya investasi dan 
menghasilkan nilai tambah (value added) sehingga memiliki dampak yang besar pada kinerja keuangan. Pengelolaan sumber daya yang baik akan menyebab)kan peningkatan dari kemampuan karyawan. Kemampuan karyawan inilah yang akan memberikan kontribusi ke dalam perusahaan dalam peningkatan profitabilitas perusahaan yang akan berujung pada tercapainya keunggulan kompetitif perusahaan (Winahyu dan Mimba, 2018)

Fenomena Intellectual Capital di Indonesia muncul sejak diterbitkannya PSAK No.19 (revisi 2012) tentang aktiva tak berwujud. Meskipun tidak dinyatakan secara langsung sebagai intellectual capital atau modal intelektual, namun intellectual capital telah mendapat perhatian. Intangible asset atau aset tak berwujud adalah aset non-moneter yang teridentifikasi tanpa wujud fisik serta dimiliki untuk digunakan dalam menghasilkan atau menyerahkan barang atau jasa, disewakan kepada pihak lainnya, atau untuk tujuan administratif. Paragraf 09 disebutkan contoh dari aktiva tak berwujud antara lain pengetahuan dan teknologi, desain dan implikasi sistem baru, lisensi, hak kekayaan intelektual (HKI), pengetahuan mengenai pasar dan merek dagang (IAI, 2012).

Penerapan bisnis berdasarkan pengetahuan (knowledge-based business) ini ditandai dengan adanya Indonesian Most Admired Knowledge Enterprise (MAKE) Study pertama kali pada tahun 2005. MAKE Study merupakan suatu bentuk pengakuan yang diberikan kepada organisasi atau perusahaan yang mengelola pengetahuannya (company knowledge) menjadi produk, jasa atau kinerja yang unggul sehingga menghasilkan nilai lebih kepada para pemegang 
saham dan pihak-pihak yang berkepentingan di dalam perusahaan tersebut (Dwipayani dan Prastiwi, 2014).

Teori Resource-Base View yang dipelopori oleh Barney (1991) berpandangan bahwa nilai ekonomis dalam keunggulan bersaing sebuah perusahaan terletak pada kepemilikan dan pemanfaatan secara efektif sumber daya organisasi yang mampu menambah nilai (valuable), bersifat langka (rare), sulit untuk ditiru (imperfectly immitable), dan tidak tergantikan oleh sumberdaya lain (non-substitutable). Maka dari itu, strategi bersaing diperlukan dalam upayaupaya mencari, mendapatkan, mengembangkan, dan mempertahankan sumber daya strategis. Sumber daya staregis tersebut adalah Intellectual Capital (IC).

Penelitian ini menggunakan metode Value Added Intellectual Coeficient (VAIC $^{\mathrm{TM}}$ ) yang dikembangkan oleh Pulic (1998) VAIC ${ }^{\mathrm{TM}}$ didesain untuk menyajikan informasi tentang efisiensi penciptaan nilai dari aset berwujud (tangible asset) dan aset tidak berwujud (intangible asset). Keunggulan metode VAIC $^{\mathrm{TM}}$ menurut Ulum (2009), adalah kemudahan dalam memperoleh data dari berbagai sumber dan jenis perusahaan. $\mathrm{VAIC}^{\mathrm{TM}}$ dianggap indikator yang cocok untuk mengukur modal intelektual pada riset empiris. Metode $\mathrm{VAIC}^{\mathrm{TM}}$ menggunakan dasar ukuran yang standar dan konsisten, angka-angka keuangan standar yang terdapat dalam laporan keuangan perusahaan.

Penelitian sebelumnya telah menunjukkan bahwa intellectual capital berpengaruh pada kinerja keuangan. Menurut Faradina dan Gayatri (2016), intellectual capital berpengaruh positif pada ROA. Penelitian Puspitosari (2016) juga menunjukkan komponen intellectual capital yang terdiri dari VACA, 
VAHU, dan STVA memiliki pengaruh signifikan pada kinerja keuangan yang diproksikan dengan ROA. Penelitian di berbagai negara lain yang berfokus pada kinerja keuangan yang dipengaruhi oleh intellectual capital dengan menggunakan metode VAIC $^{\mathrm{TM}}$ seperti yang dilakukan di Singapura (Tan et. al., 2007), Malaysia (Khalique et. al., 2013), Turki (Ozkan et. al., 2017) dan penelitian di Serbia (Bontis et. al., 2015).

Menurut teori stakeholder, perusahaan harus menjaga hubungan dengan stakeholder-nya dengan mengakomodasi keinginan dan kebutuhan stakeholdernya yang mempunyai power terhadap ketersediaan sumber daya yang digunakan untuk aktivitas operasional perusahaan, misalnya tenaga kerja, pasar atas produk perusahaan dan lain-lain (Ghozali dan Chariri, 2007). Perusahaan akan mengungkapkan suatu informasi jika informasi tersebut meningkatkan nilai perusahaan apabila dilihat dari perspektif ekonomi. Dengan melakukan kegiatan CSR perusahaan berharap memperoleh legitimasi dari masyarakat dan mempertahankan hubungan dalam lingkungan sosial dimana mereka beroperasi. Beberapa perusahaan telah sadar akan dampak yang terjadi terhadap lingkungan tempat mereka melakukan aktivitas operasional perusahannya, maka dari itu timbul suatu tanggung jawab sosial perusahaan terhadap stakeholder.

Corporate Social Responsibility (CSR) berdasarkan konsep The Triple Bottom Line sangat berpengaruh akan perhatian konsumen pada perusahaan. Ketertarikan pelanggan terhadap perusahaan juga akan berpengaruh terhadap konsumsi produk yang juga akan berdampak besar bagi laba perusahaan. Mempraktekkan tanggung jawab secara sukarela membuat perusahaan akan 
mendapatkan keunggulan dari pesaing-pesaingnya dalam sisi kompetitif dalam jangka pendek seperti peningkatan dalam produktivitas seperti mengembangkan kemampuannya untuk menarik sumber daya manusia dalam jumlah yang besar, keuntungan penjualan karena pembeli mungkin sangat sensitif terhadap isu-isu sosial dan mengurangi biaya yang diharapkan dapat dengan kreditur maupun supplier yang potensial.

Berdasarkan penelitian Karjaya dan Sisdyani (2014) mengungkapkan bahwa Corporate Social Responsibility berpengaruh positif pada kinerja keuangan perusahaan. Selain itu, hasil penelitian Rosdwianti dkk. (2016), menyatakan bahwa pengungkapan CSR berpengaruh positif signifikan pada ROA. Perusahaan akan bertumbuh baik dengan melakukan CSR dan tentu akan mendapatkan respect yang lebih daripada perusahaan yang tidak melakukan CSR.

Semakin baik perusahaan melakukan pengungkapan akan terbangun citra perusahaan yang makin baik di masyarakat akan mempunyai pandangan yang bagus karena kepentingan umum. Aktititas CSR dapat menjadi elemen yang perusahaan, memberikan kontribusi kepada manajemen risiko dan memelihara hubungan yang dapat memberikan keuntungan jangka panjang bagi perusahaan. CSR memberikan kontribusi bagi perusahaan menciptakan laba yang berdampak dari loyalitas konsumen atas produk dan jasa yang ditawarkan perusahaan. Hal ini menunjukkan bahwa ada pengaruh positif antara dalam dengan kinerja keuangan perusahaan.

Berdasarkan uraian tersebut, dapat diketahui bahwa dengan mengungkapkan CSR, akan memberikan pengaruh pada kinerja keuangan 
perusahaan. Dengan demikian, hipotesis yang dapat diajukan adalah sebagai berikut:

$\mathrm{H}_{1}$ : Corporate Social Responsibility berpengaruh positif pada kinerja keuangan perusahaan sektor perdagangan.

Berdasarkan Resource Based Theory menyebutkan bahwa keunggulan kompetitif perusahaan diperoleh dari kemampuan perusahaan untuk memanfaatkan kombinasi sumber daya yang tepat sehingga mampu meningkatkan kinerja perusahaan. Kinerja keuangan yang baik mencerminkan bahwa perusahaan telah berhasil memanfaatkan seluruh sumber daya yang dimiliki dengan baik sehingga menghasilkan keuntungan bagi perusahaan. Bagi karyawan, kinerja keuangan yang baik akan menandakan bahwa kebutuhan-kebutuhan mereka seperti gaji dan tunjangan. Bagi investor, kinerja keuangan yang baik menandakan bahwa perusahaan telah berhasil dengan baik memanfaatkan dana yang mereka investasikan.

Hal tersebut sesuai dengan yang dikemukakan Ulum (2009) yaitu jika modal intelektual merupakan sumber daya yang terukur untuk peningkatan keunggulan kompetitif, maka modal intelektual akan memberikan kontribusi pada kinerja keuangan perusahaan.

Ulum (2009) melakukan penelitian tentang hubungan antara intellectual capital pada 130 perusahaan perbankan di Indonesia. Hasil peneilitian ini menunjukkan bahwa intellectual capital berpengaruh pada kinerja keuangan perusahaan masa kini dan masa akan datang. Penelitian yang dilakukan oleh Mariyantini dan Putri (2018), menunjukkan bahwa intellectual capital berpengaruh positif pada kinerja keuangan perusahaan. Penelitian Faradina dan 
Gayatri (2016) menyatakan bahwa kinerja keuangan perusahaan positif signifikan dipengaruhi oleh intellectual capital.

Intellectual Capital berpengaruh pada keuangan perusahaan karena dengan memiliki keunggulan kompetitif yang diciptakan oleh intellectual capital, perusahaan mampu beradaptasi pada perubahan-perubahan yang ada di lingkungan bisnis, maka kinerja keuangan perusahaan dapat terjaga dengan baik dan perusahaan dapat meminimalisasi segala risiko yang akan terjadi sehingga dapat memaksimalkan kinerja keuangan yang dicapai.

Berdasarkan penjelasan yang telah diuraikan menunjukkan bahwa pengelolaan Intellectual Capital yang baik dapat menciptakan value added yang berguna dalam peningkatan kinerja keuangan perusahaan. Dengan demikian hipotesis yang dapat diajukan adalah dalam penelitian ini adalah sebagai berikut:

$\mathrm{H}_{2}$ : Intellectual Capital berpengaruh positif pada kinerja keuangan perusahaan sektor perdagangan.

\section{METODE PENELITIAN}

Lokasi penelitian ini adalah perusahaan sektor perdagangan yang terdaftar di Bursa Efek Indonesia periode 2015 hingga 2017. Data diakses melalui website resmi Bursa Efek Indonesia (www.idx.co.id). Alasan dipilihnya perusahaan sektor perdagangan dikarenakan fenomena yang berkaitan dengan masingmasing variabel yang akan diteliti. Objek dari penelitian ini adalah kinerja keuangan yang dipengaruhi oleh corporate social responsibility dan intellectual capital pada perusahaan sektor perdagangan (besar dan eceran) yang terdaftar di Bursa Efek Indonesia periode 2015 hingga 2017. 
Secara matematis return on assets (ROA) dapat dirumuskan sebagai berikut (Horne dan Wachowicz, 2005: 221):

$\mathrm{ROA}=\frac{\text { Laba bersih setelah pajak }}{\text { Total Aset }}$

Rumus perhitungan CSRDI yaitu sebagai berikut:

$\operatorname{CSRDIj}=\frac{\sum x i j}{n}$

Keterangan :

CSRDI = Corporate Social Responsibility Disclosure Index $(0 \leq \mathrm{CSRDI} \leq 1)$.

$\sum \mathrm{X}_{\mathrm{ij}} \quad=$ Jumlah item yang diungkapkan, skor 1 jika diungkapkan, skor 0 jika tidak diungkapkan

$\mathrm{n} \quad=$ Jumlah maksimal item pengungkapan CSRDI (91 item)

Value Added Intellectual Coefficient $\left(\mathrm{VAIC}^{\mathrm{TM}}\right)$ merupakan instrument yang dapat digunakan untuk mengukur kinerja Intellectual Capital perusahaan dengan data yang diperoleh dari laporan keuangan (Ulum et. al., 2014). Pengukuran model VAIC ${ }^{\mathrm{TM}}$ menggunakan rincian sebagai berikut:

Menilai kemampuan perusahaan untuk menciptakan nilai tambah (VA). Pulic (1998) menyebutkan bahwa VA merupakan selisih antara outputs (OUT) dan inputs (IN).

$\mathrm{VA}=$ Output - Input

Keterangan :

VA = selisih antara output dan input

Output $=$ total penjualan dan pendapatan lain

Input = seluruh biaya dan beban perusahaan, kecuali biaya karyawan

Menghitung VACA (Value Added Capital Employed), menunjukkan kontribusi dana yang tersedia dalam bentuk modal atau laba bersih terhadap value added organisasi.

$V A C A=\frac{V A}{C E}$ 
Keterangan:

VACA = Value Added Capital Employed (rasio dari VA terhadap CE),

$\mathrm{VA}=$ Value Added,

$\mathrm{CE} \quad=$ Capital Employed (dana yang tersedia (ekuitas, laba bersih))

Menghitung VAHU (Value Added Human Capital), menunjukkan kontribusi dana yang dinvestasikan ke dalam human capital terhadap value added organisasi.

$V A H U=\frac{V A}{H C}$

Keterangan:

VAHU = Value Added Human Capital (Rasio dari VA terhadap HC),

$\mathrm{VA}=$ Value Added,

$\mathrm{HC}=$ Human Capital (Beban karyawan),

Menghitung STVA (Structural Capital Value Added), menunjukkan

keberhasilan structural capital dalam penciptaan nilai.

$S T V A=\frac{S C}{V A}$

Keterangan:

STVA = Rasio dari SC terhadap VA,

$\mathrm{SC}=$ Structural Capital $(\mathrm{VA}-\mathrm{HC})$,

$\mathrm{VA}=$ Value Added

Menghitung Value Added Intellectual Coefficient $\left(\mathrm{VAIC}^{\mathrm{TM}}\right)$. VAIC ${ }^{\mathrm{TM}}$

merupakan penjumlahan dari 3 komponen sebelumnya, maka rumusnya:

$\mathrm{VAIC}^{\mathrm{TM}}=\mathrm{VACA}+\mathrm{VAHU}+\mathrm{STVA}$

Teknik yang digunakan dalam menganalisis data dalam penelitian ini adalah analisis regeresi linier berganda (multiple linier regression analysis). Tujuannya untuk menguji pengaruh Corporate Social Responsibility dan Intellectual Capital pada ROA. Persamaannya yaitu:

$\mathrm{Y}=\alpha+\beta_{1} \mathrm{X}_{1}+\beta_{2} \mathrm{X}_{2}+\mathrm{e}$ 
Keterangan:

$\mathrm{Y} \quad=$ Kinerja keuangan $(\mathrm{ROA})$

$\alpha \quad=$ Konstanta,

$\beta_{1}, \beta_{2}=$ Koefisien regresi variabel independen,

$\mathrm{X} 1=$ Corporate social responsibility $(\mathrm{CSR})$

$\mathrm{X} 2=$ Intellectual capital (IC)

e $\quad=$ error term, yaitu tingkat kesalahan penduga dalam penelitian

\section{HASIL DAN PEMBAHASAN}

Hasil statistik deskriptif penelitian ini dapat dilihat pada Tabel 2.

Tabel 2.

Hasil Uji Statistik Deskriptif

\begin{tabular}{lccccc}
\hline & $\mathrm{N}$ & Minimum & Maximum & Mean & Std. Deviation \\
\hline ROA & 72 & 0,0032 & 0,1893 & 0,049790 & 0,0370835 \\
CSR & 72 & 0,0659 & 0,5714 & 0,211844 & 0,1204947 \\
IC & 72 & 1,4427 & 6,3431 & 2,509704 & 0,9602565 \\
Valid N (listwise) & 72 & & & & \\
\hline
\end{tabular}

Sumber: Data Diolah, 2018

Kinerja Keuangan (ROA) dalam penelitian ini diukur dengan Return on Assets. Berdasarkan Tabel 2, nilai rata-rata (mean) variabel kinerja keuangan sebesar 0,049790 dengan standar deviasi sebesar 0,0370835 yang berarti variasi data yang rendah dan menunjukkan hasil penyebaran data yang normal dan tidak menyebabkan bias. Variabel kinerja keuangan memiliki nilai minimum sebesar 0,0032 dimiliki oleh PT Mitra Adiperkasa Tbk pada tahun 2015, sedangkan nilai maksimum sebesar 0,1893 dimiliki oleh PT Ace Hardware Indonesia Tbk pada tahun 2016. Semakin tinggi nilai ROA suatu perusahaan maka semakin baik pula penilaian para investor pada kinerja keuangan perusahaan. Semakin tinggi nilai ROA, maka kinerja keuangan suatu perusahaan akan semakin tinggi pula.

Corporate Social Responsibility (CSR) ini diukur dengan Corporate Social Responsibility Disclosure Index (CSRDI). Berdasarkan Tabel 2, nilai rata-rata variabel CSR sebesar 0,211844 dengan standar deviasi sebesar 0,1204947. Nilai 
minimum sebesar 0,0659 dimiliki oleh PT Millennium Pharmacon International Tbk tahun 2016 sampai 2017 dan PT Dua Putra Utama Makmur Tbk serta PT FKS Multi Agro Tbk tahun 2015, sedangkan nilai maksimum sebesar 0,5714 dimiliki oleh PT United Tractors Tbk tahun 2015. Hasil ini menunjukkan variasi pengungkapan CSR perusahaan cenderung rendah karena item yang diungkapkan perusahaan sampel masih jauh dari kriteria GRI G.4 yang mengungkapkan 91 item.

Intellectual Capital (IC) dalam penelitian ini diukur dengan Value Added Intellectual Capital (VAIC). Berdasarkan Tabel 2, nilai rata-rata variabel Intellectual Capital sebesar 2,509704 dengan standar deviasi sebesar 0,9602565. Standar deviasi lebih kecil dari nilai rata-rata menunjukkan bahwa variasi data ini rendah. Nilai minimum sebesar 1,4427 dimiliki oleh PT Wicaksana Overseas International Tbk tahun 2015, sedangkan nilai maksimum sebesar 6,3431 dimiliki oleh PT Dua Putra Utama Makmur Tbk tahun 2015.

Hasil analisis regresi linier berganda dapat dilihat pada Tabel 3.

Tabel 3.

Rekapitulasi Hasil Analisis Regresi Linier Berganda

\begin{tabular}{cccccc}
\hline Model & \multicolumn{2}{c}{ Unstandardized Coefficients } & $\begin{array}{c}\text { Standardized } \\
\text { Coefficients }\end{array}$ & $\mathrm{t}$ & Sig. \\
& $\mathrm{B}$ & Std. Error & Beta & & \\
\hline (Constants) & $-4,004$ & 0,390 & & $-10,279$ & 0,000 \\
CSR & 0,112 & 0,153 & 0,079 & 0,729 & 0,469 \\
IC & 1,091 & 0,252 & 0,470 & 4,328 & 0,000 \\
\hline
\end{tabular}

Sumber: Data diolah, 2018

Berdasarkan Tabel 3, maka dihasilkan persamaan regresi sebagai berikut.

$$
Y=-4,004+0,112 X_{1}+1,091 X_{2}
$$

Keterangan:

$\mathrm{Y} \quad=$ Kinerja Keuangan

$\mathrm{X}_{1} \quad=$ Corporate Social Responsibility (CSR) 
Made Cahyani Prastuti dan I G. A. N. Budiasih. Pengaruh ...

$\mathrm{X}_{2} \quad=$ Intellectual Capital (IC)

e $\quad=$ error term, yaitu tingkat kesalahan penduga dalam penelitian

Nilai konstanta $(\alpha)$ sebesar $-4,004$ memiliki arti bahwa apabila pengungkapan CSR dan Intellectual Capital adalah 0 atau tidak dipertimbangkan, maka kinerja keuangan (Y) memiliki nilai -4,004.

Nilai koefisien regresi pengungkapan CSR $\left(\mathrm{X}_{1}\right)$ sebesar 0,112 memiliki arti bahwa apabila pengungkapan CSR meningkat sebesar 1 satuan, maka kinerja keuangan (Y) meningkat sebesar 0,112 satuan dengan asumsi variabel lainnya konstan.

Nilai koefisien regresi IC $\left(\mathrm{X}_{2}\right)$ adalah sebesar 1,091 memiliki arti bahwa apabila nilai variabel Intellectual Capital (IC) mengalami kenaikan sebesar 1 satuan, maka maka kinerja keuangan (Y) meningkat sebesar 1,091 satuan dengan asumsi variabel lainnya konstan.

Pada penelitian ini koefisien determinasi dilihat melalui nilai adjusted $\mathrm{R}^{2}$. Adapun nilai dari adjusted $\mathrm{R}^{2}$ pada penelitian ini disajikan pada Tabel 4.9.

Tabel 4.

Hasil Uji Koefisien Determinasi $\left(\mathbf{R}^{2}\right)$

\begin{tabular}{ccccc}
\hline Model & $\mathrm{R}$ & $\mathrm{R}^{2}$ & Adjusted $\mathbf{R}^{2}$ & $\begin{array}{c}\text { Std. Error of the } \\
\text { Estimate }\end{array}$ \\
\hline 1 & 0,497 & 0,247 & 0,226 & 0,65764 \\
\hline Sumber: & Data diolah & 2018 & &
\end{tabular}

Pada Tabel 4, diketahui bahwa nilai dari adjusted $\mathrm{R}^{2}$ adalah sebesar 0,226 yang berarti bahwa 22,6 persen variasi perubahan kinerja keuangan dapat dijelaskan oleh variabel Corporate Social Responsibility (CSR) dan Intellectual Capital (IC). Sisanya adalah sebesar 77,4 persen dipengaruhi oleh variabel lain diluar dari model yang digunakan dalam penelitian ini. 
Hasil yang diperoleh dari pengujian kelayakan model dalam penelitian ini disajikan pada Tabel 5 .

Tabel 5.

Hasil Uji Kelayakan Model (Uji F)

\begin{tabular}{llccccc}
\hline Model & & Sum of Squares & df & Mean Square & F & Sig. \\
\hline 1 & Regression & 9,813 & 2 & 4,907 & 11,345 & $0,000^{\mathrm{a}}$ \\
& Residual & 29,842 & 69 & 0,432 & & \\
& Total & 39,655 & 71 & & & \\
\hline
\end{tabular}

Sumber: Data diolah, 2018

Berdasarkan Tabel 5, dapat dilihat bahwa nilai dari Uji $\mathrm{F}$ adalah sebesar 11,345 dan nilai Sig. F yakni 0,000 lebih kecil dari nilai $\alpha=0,05$. Hal ini menunjukkan bahwa model yang digunakan dalam penelitian ini layak untuk digunakan sebagai alat analisis untuk menguji pengaruh variabel independen pada variabel dependen.

Uji t dilakukan dengan membandingkan hasil nilai signifikansi dengan $\alpha=$ 0,05. Hasil statistik uji t disajikan dalam Tabel 6.

Tabel 6.

Hasil Uji Statistik t

\begin{tabular}{|c|c|c|c|c|c|}
\hline \multirow[t]{2}{*}{ Model } & \multicolumn{2}{|c|}{ Unstandardized Coefficients } & \multirow{2}{*}{$\begin{array}{c}\text { Standardized } \\
\text { Coefficients } \\
\text { Beta } \\
\end{array}$} & \multirow[t]{2}{*}{$\mathrm{t}$} & \multirow[t]{2}{*}{ Sig. } \\
\hline & $\mathrm{B}$ & Std. Error & & & \\
\hline (Constants) & $-4,004$ & 0,390 & & $-10,279$ & 0,000 \\
\hline CSR & 0,112 & 0,153 & 0,079 & 0,729 & 0,469 \\
\hline $\mathrm{IC}$ & 1,091 & 0,252 & 0,470 & 4,328 & 0,000 \\
\hline
\end{tabular}

Sumber: Data diolah, 2018

Berdasarkan Tabel 6 dapat diketahui bahwa Corporate Social Responsibility (CSR) memiliki nilai signifikansi sebesar 0,469>0,05 maka $\mathrm{H}_{1}$ ditolak dan $\mathrm{H}_{0}$ diterima. Hasil ini mempunyai arti bahwa Corporate Social Responsibility (CSR) tidak berpengaruh pada kinerja keuangan perusahaan perdagangan. Pada Tabel 4.11 juga dapat diketahui bahwa Intellectual Capital (IC) memiliki nilai signifikansi sebesar $0,000<0,05$ maka $\mathrm{H}_{0}$ ditolak dan $\mathrm{H}_{2}$ 
diterima. Hasil ini mempunyai hasil bahwa Intellectual Capital (IC) berpengaruh positif pada kinerja keuangan perusahaan perdagangan.

Hasil analisis menunjukkan bahwa pengungkapan Corporate Social Responsibility (CSR) tidak berpengaruh pada kinerja keuangan perusahaan sektor perdagangan. Hasil penelitian in tidak sesuai dengan hipotesis yang menyatakan bahwa pengungkapan CSR berpengaruh positif pada kinerja keuangan perusahaan sektor perdagangan. Hal ini menandakan tinggi rendahnya pengungkapan CSR tidak akan berdampak pada kinerja keuangan sektor perdagangan. Pengungkapan CSR tidak berpengaruh pada kinerja keuangan perusahaan disebabkan kurangnya pemahaman dari masyarakat tentang aktivitas corporate social responsibility dari perusahaan sehingga menyebabkan tingkat kepedulian masyarakat secara umum kurang baik. Artinya, sekalipun perusahaan telah melakukan kepedulian terhadap lingkungan sosialnya, maka usaha tersebut tidak akan mempunyai dampak yang signifikan pada kinerja keuangan perusahaan.

Hasil uji statistik penelitian ini memiliki hasil yang bertentangan dengan penelitian Karjaya dan Sisdyani (2014) juga Rosdwianti et al. (2016) yang menyatakan bahwa CSR berpengaruh positif pada kinerja keuangan perusahaan. Hasil penelitian ini sejalan dengan hasil penelitian Budiasih (2015) yang menyatakan bahwa pengungkapan Corporate Social Responsibility tidak berpengaruh pada profitabilitas perbankan. Perbedaan penelitian ini terletak pada indikator pengukur pengungkapan CSR dan sektor perusahaan yang diteliti. Penelitian Budiasih (2015) mengacu pada GRI 3.1 pada sektor perbankan, 
sedangkan penelitian ini menggunakan indikator GRI-G4 pada sektor perdagangan.

Wibisono (2007) menyatakan bahwa sulit untuk menentukan benefit perusahaan yang menerapkan CSR, karena tidak ada yang dapat menjamin bahwa bila perusahaan telah mengimplementasikan CSR dengan baik maka akan mendapatkan kepastian benefit. Jika dilihat dari data statistik deskriptif didapat bahwa rata rata pengungkapan aktivitas CSR di perusahaan perdagangan masih sekitar 21,18 persen dari total indikator pengungkapan GRl. Menurut (Yaparto dkk. , 2013) umumnya perusahaan melakukan pengungkapan CSR hanya sebagai bagian dari iklan dan menghindari untuk memberikan informasi yang relevan. Oleh karena itu, tidak jarang perusahaan akan mengungkapkan hal-hal yang baik dan menutupi hal yang menurut perusahaan tidak memberikan keuntungan. Perusahaan berharap agar para pengguna laporan akan membaca "good news" kinerja perusahaan, misalnya dalam lingkup sosial. Hal ini memicu penurunan kualitas pengungkapan CSR sehingga investor tidak menggunakan informasi tersebut sebagai dasar untuk pengambilan keputusan.

Hasil ini tidak mampu mengkonfirmasi teori stakeholder yang menjelaskan bahwa perusahaan bukanlah entitas yang beroperasi hanya untuk kepentingan shareholders namun harus bermanfaat bagi stakeholders untuk menunjang keberlangsungan usaha melalui pengungkapan CSR. Hasil penelitian ini menujukkan bahwa pengungkapan CSR pada perusahaan sektor perdagangan belum dapat menyajikan informasi mengenai aktivitas perusahaan yang bisa berdampak pada stakeholder. Hasil penelitian ini juga tidak mampu 
mengkonfirmasi teori legitimasi yang menyatakan bahwa perusahaan harus mampu mengungkapkan berbagai aktivitas operasionalnya untuk mendapatkan penerimaan dari masyarakat atas bisnis yang dijalaninya. Beberapa informasi yang dapat memperkuat legitimasi, misalnya penghargaan lingkungan yang pernah diraih maupun program sosial yang telah diterapkan perusahaan belum dapat diterima oleh masyarakat.

Hasil analisis menunjukkan bahwa intellectual capital berpengaruh pada kinerja keuangan. Hasil penelitian ini mendukung hipotesis yang menyatakan bahwa intellectual capital berpengaruh positif pada kinerja keuangan perusahaan sektor perdagangan. Hal ini mengindikasikan jika semakin tinggi intellectual capital maka semakin tinggi pula kinerja keuangan perusahaan. Intellectual Capital berpengaruh pada keuangan perusahaan karena dengan memiliki keunggulan kompetitif yang diciptakan oleh intellectual capital, perusahaan mampu beradaptasi pada perubahan-perubahan yang ada di lingkungan bisnis, maka kinerja keuangan perusahaan dapat terjaga dengan baik dan perusahaan dapat meminimalisasi segala risiko yang akan terjadi sehingga dapat memaksimalkan kinerja keuangan yang dicapai.

Hasil penelitian ini konsisten dengan hasil penelitian yang dilakukan oleh Ulum (2009) dan Mariyantini dan Putri (2018) yang juga menyatakan bahwa Intellectual Capital yang diukur menggunakan VAIC berpengaruh signifikan pada kinerja keuangan yang diproksikan dengan ROA. Intellectual Capital mencerminkan sumber daya yang dimiliki perusahaan berupa pengetahuan untuk menghasilkan aset yang lebih tinggi. Penelitian Faradina dan Gayatri (2016) 
menjelaskan apabila perusahaan memiliki intellectual capital yang baik maka kinerja keuangan perusahaan dalam laporan keuangan juga meningkatkan kepercayaan para stakeholder terhadap perusahaan, karena stakeholder percaya dengan perusahaan sehingga stakeholder mau berinvestasi pada perusahaan tersebut. Hal ini dikarenakan perusahaan lebih memaksimalkan pemanfaatan asetnya untuk mendorong kualitas karyawan yang dimiliki guna meningkatkan laba yang dihasilkan.

Hal ini sejalan dengan Resource Based Theory yang menyimpulkan bahwa sumber daya dan pengetahuan yang dikelola perusahaan dengan baik maka perusahaan tersebut akan memiliki keunggulan kompetitif yang memiliki pengaruh pada kinerja perusahaan. Penelitian ini juga mengkonfirmasi stakeholder theory yaitu individu, kelompok atau organisasi baik secara keseluruhan atau secara parsial yang memiliki kekuasaan, kepentingan serta menghadapi risiko akibat kegiatan perusahaan tersebut baik secara langsung ataupun tidak langsung (Kusuma dan Mahmud, 2015). Stakeholder theory menjelaskan bagaimana memelihara hubungan yang mencangkup pekerja, masyarakat, pemasok, investor maupun kreditor. Hubungan yang dimiliki perusahaan kepada pihak-pihak yang terlibat dalam kegiatan perusahaan tersebut harus dikelola dengan baik untuk tujuan saling mempengaruhi dan untuk mencari keuntungan. 


\section{SIMPULAN}

Pengungkapan Corporate Social Responsibility tidak berpengaruh pada kinerja keuangan di perusahaan perdagangan yang terdaftar di BEI periode 2015-2017. Pengungkapan CSR tidak berpengaruh pada kinerja keuangan perusahaan diakibatkan kurangnya pemahaman dari masyarakat tentang aktivitas corporate social responsibility dari perusahaan sehingga menyebabkan tingkat kepedulian masyarakat secara umum kurang baik. Selain itu, manajemen kurang konsisten dalam merencanakan, melaksanakan dan mengungkapkan aktivitas corporate social responsibility sehingga investor tidak cukup yakin dengan informasi sukarela seperti pengungkapan CSR yang diungkapkan pihak manajemen perusahaan.

Intellectual Capital berpengaruh positif pada kinerja keuangan perusahaan perdagangan yang terdaftar di BEI periode 2015-2017. Artinya semakin tinggi intellectual capital maka semakin tinggi pula kinerja keuangan perusahaan. Kombinasi intellectual capital dapat menciptakan value added yang dapat memberikan manfaat ekonomi jangka panjang bagi perusahaan. Apabila perusahaan dapat dengan efektif dan efisien memberdayakan intellectual capital yang dimiliki maka perusahaan bisa meminimalisir biaya-biaya yang terjadi di perusahaan. Adanya kombinasi intellectual capital didukung dengan penurunan biaya-biaya akan meningkatkan laba yang diperoleh perusahaan, sehingga kinerja keuangan perusahaan juga akan meningkat.

Bagi perusahaan diharapkan mampu melakukan aktivitas tanggungjawab sosial dan mengungkapkannya secara optimal sebagai wujud kepedulian pada 
aspek lingkungan dan sosial. Terkait dengan sektor perdagangan yang kegiatan operasionalnya tidak langsung bersentuhan dengan alam dan ekosistem lingkungan, sebaiknya lebih meningkatkan jumlah pengungkapan diluar aspek lingkungan seperti pada aspek ekonomi dan aspek sosial. Berdasarkan hasil penelitian ini pengungkapan kategori sosial mendapat skor terendah, khususnya pada sub kategori Hak Asasi Manusia, masyarakat, dan tanggungjawab atas produk. Peningkatan pada kategori tersebut diharapkan dapat berdampak pada tingkat kepercayaan stakeholder yang akan berpengaruh pada kinerja keuangan perusahaan. Bagi perusahaan juga diharapkan untuk lebih memaksimalkan intellectual capital yang dimiliki. Berdasarkan hasil penelitian ini pengukuran atas Value Added of Capital Employed (VACA) dan Structural Capital Value Added (STVA) mendapatkan poin terendah. Diharapkan perusahaan mampu meningkatkan kategori tersebut, mengingat pentingnya intellectual capital dan investasi yang ditanamkan pada intellectual capital dapat berdampak pada kinerja keuangan perusahaan.

Bagi para investor diharapkan lebih menyadari pentingnya isu corporate social responsibility (CSR) di masa depan baik secara menyeluruh maupun berdasarkan pada parameternya. Hal ini disebabkan karena dengan melakukan CSR menunjukkan bahwa perusahaan telah memilki laba yang tinggi sehingga mampu merealisasikan labanya dengan melakukan aktivitas CSR, yang nantinya akan mendapatkan citra positif dan masyarakat. Citra yang positif ini akan meningkatkan nilai perusahaan. Investor yang menanamkan modalnya 
diperusahaan tersebut akan memperoleh keuntungan yang lebih. Jadi, CSR perlu dipertimbangkan oleh investor dalam pengambilan keputusan investasi.

Berdasarkan hasil uji koefisien determinasi $\left(\mathrm{R}^{2}\right)$ pada penelitian ini hanya sebesar 22,6 persen yang menunjukkan adanya keterbatasan variabel independen yang digunakan dalam penelitian ini untuk menjelaskan variabel dependen. Dari total 100 persen, variabel independen hanya dapat menjelaskan 22,6 persen dari variabel dependen di penelitian ini, sedangkan sisanya sebesar 77,4 persen dipengaruhi oleh variabel lain diluar dari model yang digunakan dalam penelitian ini. Artinya terdapat faktor-faktor lain diluar dari model penelitian ini yang dapat mempengaruhi kinerja keuangan perusahaan. Penelitian selanjutnya disarankan untuk dapat menambah atau mempertimbangkan kemungkinan variabel independen lainnya yang dapat mempengaruhi kinerja keuangan perusahaan, misalnya struktur modal dan efisiensi modal kerja. Apabila ingin meneliti pengaruh corporate social responsibility diharapkan untuk menggunakan variabel reaksi pasar atau nilai perusahaan.

\section{REFERENSI}

Abriyani, D. R., Wiryono, S. K., \& Sumirat, E. (2012). The Effect of Good Corporate Governance and Financial Performance on the Corporate Social Responsibility Disclosure of Telecommunication. The Indonesian Journal of Business Administration, 1(5), 296-300.

Barney, J. (1991). Firm Resource and Sustained Competitive Advantage. Journal of Management.

Bontis, N., Janošević, S., \& Dženopoljac, V. (2015). Intellectual capital in Serbia's hotel industry. International Journal of Contemporary Hospitality Management, 27(6), 1365-1384. https://doi.org/10.1108/IJCHM-12-20130541 
Budiasih, I. G. N. (2015). Intellectual Capital dan Corporate Social Responsibility Pengaruhnya Pada Profitabilitas Perbankan. Jurnal Dinamika Akuntansi, 7(1), 75-84.

Dwipayani, C. C., \& Prastiwi, A. (2014). Pengaruh Intellectual Capital Terhadap Profitabilitas dan Kinerja Pasar. DIPONEGORO JOURNAL OF ACCOUNTING, 3(3), 1-9.

Elkington, J. (1998). Partnerships from cannibals with forks: The triple bottom line of 21st- century business. Environmental Quality Management, 8(1), $37-51$.

Faradina, I., \& Gayatri. (2016). Pengaruh Intellectual Capital dan Intellectual Capital Disclosure Terhadap Kinerja Keuangan Perusahaan. E-Jurnal Akuntansi Universitas Udayana, 15(2), 1623-1653.

Gantino, R. (2016). Pengaruh Corporate Social Responsibility Terhadap Kinerja Keuangan Perusahaan Manufaktur yang Terdaftar di Bursa Efek Indonesia periode 2008-. Jurnal Dinamika Akuntansi Dan Bisnis, 3(2), 19-32.

Ghoul, S. El, Guedhami, O., Kwok, C. C. Y., \& Mishra, D. R. (2011). Does corporate social responsibility affect the cost of capital? Journal of Banking and Finance, 35(9), 2388-2406. https://doi.org/10.1016/j.jbankfin.2011.02.007

Guthrie, J., \& Petty, R. (2000). Intellectual capital literature review: measurement, reporting and management. Journal of Intellectual Capital, 1(2), 155-176.

Harun, U. (2016). Pengaruh Ratio-Ratio Keuangan CAR, LDR, NIM, BOPO, NPL Terhadap ROA. Journal Riset Bisnis Dan Manajemen, 4(1), 67-82.

Hermawan, S., \& Mardiyanti, U. I. (2016). Intellectual Capital Dan Kinerja Keuangan Pada Perusahaan Sektor Keuangan. BENEFIT Jurnal Managemen Dan Bisnis, 1(1), 70-78.

IAI. PSAK No. 19 (revisi 2000) (2012).

Jananti, N. W. R., \& Setiawan, P. E. (2018). Pengaruh Agresivitas Pajak pada Corporate Social Responsibility dengan Profitabilitas sebagai Variabel Moderasi. E-Jurnal Akuntansi Universitas Udayana, 24(2018), 170-195.

Karjaya, I. W. H., \& Sisdyani, E. A. (2014). Pengaruh Tingkat Pengungkapan CSR Dan Mekanisme GCG Pada Kinerja Keuangan Perusahaan Pertambangan. E-Jurnal Akuntansi Universitas Udayana, 8(3), 620-629. 
Khalique, M., Nassir Shaari, J. A., Isa, A. H. B. M., \& Samad, N. (2013). Impact of Intellectual Capital on the Organizational Performance of Islamic Banking Sector in Malaysia. Asian Journal of Finance \& Accounting, 5(2), 75-83. https://doi.org/10.2139/ssrn.2327407

Kusuma, H., \& Mahmud, M. (2015). Pengaruh Intellectual Capital Terhadap Kinerja Keuangan Dan Nilai Pasar Pada Perusahaan Manufaktur Yang Terdaftar Di Bursa Efek Indonesia ( Pengujian Dengan Persamaan Simutan ). Jurnal STIE Ekonomi, 16-28.

Mariyantini, N. L. P. N., \& Putri, I. G. A. M. A. D. (2018). Pengaruh CSR dan Intellectual Capital Pada Kinerja Keuangan Perbankan Yang Terdaftar di BEI Periode 2013-2016. E-Jurnal Akuntansi Universitas Udayana, 23(2), 1171-1200. https://doi.org/https://doi.org/10.24843/EJA.2018.v23.i02.p14 Pengaruh

Mukharomah, W., \& Kesumaningrum, L. P. (2014). Pengaruh Corporate Social Responsibility Terhadap Profitabitabilitas Pada Perusahaan Food and Beverages Di Bursa Efek Indonesia (Bei) Tahun 2007-2010. Journal of Chemical Information and Modeling, 53(Seminar Nasional dan Call for Paper), 342-366. https://doi.org/10.1017/CBO9781107415324.004

Noorkhaista, E., \& Sari, D. (2017). Kinerja Modal Intelektual, Keragaman Gender dan Keragaman Kewarganegaraan Dalam Dewan Direksi. AKRUAL: Jurnal Akuntansi, 9(1), 1-19.

Ozkan, N., Cakan, S., \& Kayacan, M. (2017). Intellectual capital and financial performance: A study of the Turkish Banking Sector. Borsa Istanbul Review, 17(3), 190-198. https://doi.org/10.1016/j.bir.2016.03.001

Pulic, A. (1998). Measuring the Performance of Intellectual Potential in Knowledge Economy.

Puspitosari, I. (2016). Modal Intelektual Dan Kinerja Keuangan Dengan Menggunakan Islamicity Performance Index Pada Bank Umum Syariah. Hunafa: Jurnal Studia Islamika, 13(2), 248-270.

Rosdwianti, M. K., Dzulkirom, M., \& Zahroh, Z. . (2016). Pengaruh Corporate Social Responsibility (CSR) Terhadap Profitabilitas Perusahaan (Studi Pada Sektor Industri Barang Konsumsi Yang Terdaftar Di Bursa Efek Indonesia Periode 2013-2014). Jurnal Administrasi Bisnis (JAB), 38(2), 16-22. https://doi.org/10.1097/BSD.0b013e318291cb61

Sawarjuwono, T., \& Kadir, A. P. (2003). Intellectual Capital: Perlakuan, Pengukuran Dan Pelaporan (Sebuah Library Research). Jurnal Akuntansi Dan Keuangan, 5(1), 35-57. https://doi.org/10.1024/0301-1526.32.1.54 
Tan, H. P., Plowman, D., \& Hancock, P. (2007). Intellectual capital and financial returns of companies. Journal of Intellectual Capital, 8(1), 76-95.

Ulum, I. (2009). Intellectual Capital Performance Sektor Perbankan di Indonesia. Jurnal Akuntansi Dan Keuangan, 10(2), 77-84. https://doi.org/10.1108/14691930310472839

Ulum, I., Ghozali, I., \& Purwanto, A. (2014). Intellectual Capital Performance of Indonesian Banking Sector: A Modified VAIC (M-VAIC) Perspective. Asian Journal of Finance \& Accounting, 6(2), 103-123. https://doi.org/10.5296/ajfa.v6i2.5246

Umawan, A. A. N. K. P., \& Putri, I. G. A. M. A. D. (2017). Analisis Pengungkapan Dan Dampak Penerapan Corporate Social Responsibility Di Hotel the Westin Resort Nusa Dua. E-Jurnal Akuntansi Universitas Udayana, 19(1), 27-50.

Wibisono, Y. (2007). Membedah konsep \& aplikasi CSR: corporate social responsibility.

Williams, S. M. (2001). Is intellectual capital performance and disclosure practices related? Journal of Intellectual Capital. https://doi.org/10.1108/14691930110399932

Winahyu, N. W. R., \& Mimba, N. P. S. H. (2018). Intellectual Capital sebagai Pemoderasi Pengaruh Debt to Equity Ratio dan Ukuran Perusahaan pada Profitabilitas. E-Jurnal Akuntansi Universitas Udayana, 23(1), 734-760.

Wulandari, A. A., Ramantha, I. W., \& Wirakusuma, M. G. (2016). Dampak Moderasi Profitabilitas terhadap Pengaruh Corporate Social Responsibility pada Nilai Perusahaan Manufaktur. E-Jurnal Ekonomi Dan Bisnis Universitas Udayana, 5(7), 1889-1918.

Yaparto, M., K., D. F., \& Eriandani, R. (2013). Pengaruh Corporate Social Responsibility Terhadap Kinerja Keuangan Pada Sektor Manufaktur Yang Terdaftar Di Bursa Efek Indonesia Pada Periode 2010-2011. Jurnal Ilmiah Mahasiswa Universitas Surabaya, 2(1), 1-19. 